\title{
PERIOPERATIVE CEFUROXIME PHARMACOKINETICS IN CARDIAC SURGERY
}

Jorge Willian Leandro Nascimento, Maria José Carvalho Carmona, Tânia Mara

Varejão Strabelli, José Otávio Costa Auler Jr, Sílvia Regina Cavani Jorge Santos

Nascimento JWL, Carmona M JC, Strabelli T M V, Auler Jr J O C, Santos S RCJ. Perioperative Cefuroxime Pharmacokinetics in Cardiac Surgery. Clinics. 2007;62(3):257-60.

OBJECTIVE: The objective was to investigate the plasma levels and to compare the pharmacokinetics of cefuroxime during and after surgery in adult patients with elective indication for coronary artery bypass grafting.

METHODS: Seventeen patients received three 1.5-g bolus IV doses of cefuroxime, one every $12 \mathrm{hrs}$. Serial blood samples ( $3 \mathrm{~mL}$ ) were collected 1,3,6, 9, and $12 \mathrm{hrs}$ after the first dose (given during the intervention) and after the second and third doses (postsurgery). Blood samples were centrifuged and stored frozen until being assayed. For assessment of the cefuroxime plasma levels by liquid chromatography, only $200 \mu \mathrm{L}$ of plasma were required. Determination of cefuroxime plasma levels was followed by a pharmacokinetic (PK)-modeling using PK Solutions 2.0 software.

RESULTS: The kinetic parameters obtained remained unchanged after the first, second, and the third dose as follows: elimination halflife: $1.8 \mathrm{~h}, 1.9 \mathrm{~h}$, and $1.8 \mathrm{~h}$; clearance: $1.4,1.5$, and $1.5 \mathrm{~mL} / \mathrm{min} / \mathrm{kg}$, respectively. Additionally, the apparent volume of distribution did not change during and after the intervention: $0.19,0.25$, and $0.22 \mathrm{~L} / \mathrm{kg}$, after the first, second, and the third dose, respectively. Since the drug has a low volume of distribution, plasma levels obtained after a 1.5-g IV bolus injection of cefuroxime decreased rapidly due to the high plasma clearance, with a consequent short half-life.

CONCLUSIONS: The kinetic disposition of cefuroxime remains unaltered in patients undergoing coronary artery bypass grafting; to reduce the fluctuation in plasma concentrations so that the antibiotic prophylaxis in the peri-operative period is guaranteed, the dose regimen should be reviewed.

KEYWORDS: Cefuroxime. Pharmacokinetics. Antibiotic prophylaxis. HPLC. Heart surgery.

\section{INTRODUCTION}

Myocardial revascularization surgery is a common procedure, but despite clinical and surgical advances, nosocomial infection continues to be a reality for hospitals worldwide, endangering patients' rehabilitation. Prophylactic antimicrobial regimens have been used since the 1960s in such patients, aiming to reduce the incidence of infection, time of hospitalization, and consequently, treatment costs. ${ }^{1,2}$

The nature of the antibiotics and the dosing regimens (dose and frequency of administration) vary according to current hospital protocols, type of surgery, and surgical procedures. ${ }^{1-4}$

Due to the low toxicity and good tissue penetration, second generation cephalosporin is the antibiotic of choice for

Pharmacy Department - School of Pharmaceutical Sciences, University Medical School Heart Institute - São Paulo, Brazil.

Email: willian@usp.br

Received for publication on August 25, 2006.

Accepted for publication on January 04, 2007. the prophylaxis of postsurgical infections in many surgeries, including cardiac surgery. Cefuroxime has a good costbenefit relationship, with a reasonable price compared with other cephalosporins, as well as a favorable spectrum of action, preventing the growth of most bacteria found in postoperative site infections; therefore, it is highly recommended for antibiotic prophylaxis. ${ }^{1,2}$

In the present study, the pharmacokinetics of cefuroxime in the peri-operative period in patients undergoing coronary artery bypass grafting $(\mathrm{CABG})$ as well the plasma concentrations after a dosing regimen applied for antimicrobial prophylaxis were investigated.

\section{MATERIALS AND METHODS}

\section{Patients and clinical procedures}

The study protocol was approved by the hospital's Ethics Committee, and a signed written informed consent was 
obtained from all the patients. Seventeen adult patients, 11 men and 6 women scheduled for CABG in the Instituto do Coração, Hospital das Clínicas, Faculty of Medicine, Univ. São Paulo were enrolled in the study. Inclusion criteria were as follows: a) left ventricular ejection fraction $>50 \%$ and normal right ventricular function, as assessed by preoperative transthoracic echocardiography within a week before surgery, b) hepatic and renal functions monitored during all investigations were in the reference range for serum AST, ALT, total bilirubin, and creatinine; additionally, renal function was assessed by creatinine clearance estimated based on serum creatinine for all patients investigated. Patients with diabetes mellitus, chronic obstructive pulmonary disease, or peripheral artery vascular disease were excluded.

Characteristics of patients and duration of surgery were as follows (expressed as mean $\pm \mathrm{SD}$ ): age: $50.7 \pm 9.1$ years, weight: $71.2 \pm 8.7 \mathrm{~kg}$, height: $166.9 \pm 8.3 \mathrm{~cm}$, and BMI: $25.7 \pm 2.7 \mathrm{~kg} / \mathrm{m}^{2}$. The duration of surgery was $4.0 \pm 1.1 \mathrm{~h}$. Any occurrence of surgical site infection in the patients included in the protocol was verified. Additionally, no patient presented significant bleeding during the surgery, and no blood transfusion during or after the surgery was reported.

Prophylactic cefuroxime was given during the peri-operative period, and $31.5 \mathrm{~g}$ doses were administered at $12 \mathrm{hr}$ intervals, as follows: preoperative (first dose immediately before the beginning of the surgery), immediate (12 hr) and late postoperative period (24hr). Serial $3-\mathrm{mL}$ blood samples were collected 1, 3, 6, 9, and 12 hours after each dose.

Blood samples were centrifuged and stored frozen until being assayed by high-pressure liquid chromatography (HPLC) as described previously for cefuroxime in plasma. ${ }^{5}$

Only $200 \mu \mathrm{L}$ of plasma was required for the assay because of the addition of $0.0025 \mathrm{mg} /$ assay vancomycin (internal standard $100 \mathrm{mg} / \mathrm{L}$ ) and $0.4 \mathrm{~mL}$ of acetonitrile for the precipitation of plasma proteins; the mixture was vortexed, followed by centrifugation at $10000 \mathrm{~g}$ for $20 \mathrm{~min}$, and residue was discarded. Volumes of $0.2 \mathrm{~mL}$ of the supernatant were transferred to conical tubes and evaporated under a stream of nitrogen; the residue was dissolved in a mixture of water and acetonitrile (6:4 $\mathrm{v} / \mathrm{v}$ ) and injected automatically into the HPLC device. A NovaPak C18, 150 x 4.5 mm, 5-micron column containing C18 inserts and a mobile phase containing $0.375 \mathrm{M}$ acetate buffer and acetonitrile (94:6, v/v) at a flow rate of $1 \mathrm{~mL} / \mathrm{min}$ was used. The internal standard (vancomycin) and cefuroxime were eluted from the column at $4.0 \mathrm{~min}$ and $12.5 \mathrm{~min}$, respectively, and peaks were monitored by a UV detector at a $280 \mathrm{~nm}$ wavelength. The method had the following characteristics: 0.2-200 $\mathrm{mg} / \mathrm{L}$ (linearity; $\mathrm{r}^{2} 0.9963$ ), $0.2 \mathrm{mg} / \mathrm{L}$ (limit of quantification), $0.1 \mathrm{mg} / \mathrm{L}$ (limit of detection), 3.2\% and $4.2 \%$ intra- and interday precision, respectively, and the systematic error showing intra- and inter-day accuracy of 98.2 and $96.9 \%$, respectively.
A good recovery $(99.2 \%)$ and stability higher than 24 hours at room temperature were obtained for the analytical method. ${ }^{5}$

\section{Pharmacokinetics and Statistics}

Pharmacokinetic modeling was obtained by plotting cefuroxime plasma levels (logarithmic transformation) against time. The software, PK Solutions version 2.0 (Summit Research Services, Montrose, Colorado, USA), was applied to the data obtained using a 1-compartment open model after intravenous dose administration. Kinetic parameters, including elimination rate constant $(\mathrm{Kel})$, biological half-life $(\mathrm{t} 1 / 2 \beta)$, plasma clearance rate $\left(\mathrm{CL}_{\mathrm{T}}\right)$, and apparent volume of distribution $(\mathrm{Vd})$, were determined after the first, second, and third doses given to each patient investigated (during and after surgery).

The theoretical maximum cefuroxime plasma concentration ( 0 hour) was obtained by back extrapolation of the plasma decay curve, ie, the logarithmic transformation of cefuroxime plasma concentration ( $\mathrm{Y}$ axis) vs time ( $\mathrm{X}$ axis).

Data estimated or parameters obtained after PK-modeling were statistically analyzed by the nonparametric Mann-Whitney test for paired data via the comparison of cefuroxime administered at the pre- versus postoperative periods for all patients, using GraphPad Instat software, version 2.01 (San Diego, USA), with a $P$ value $<.05$ being considered significant.

\section{RESULTS}

The plasma drug decay curve after cefuroxime administration (first, second, and third doses) during and after surgery are shown in Figure 1, with values expressed as mean +/- SEM. Plasma concentration at 0 was obtained by back extrapolation of the plasma curve decay (logarithmic transformation of plasma concentration).

The kinetic parameters were expressed in terms of median and the variation range of the $95 \%$ confidence interval, since a nonparametric test was applied in the statistics. The pharmacokinetics of cefuroxime for each patient after the administration of the second and third doses was compared to the that after the first dose, which was given preoperatively (Table1).

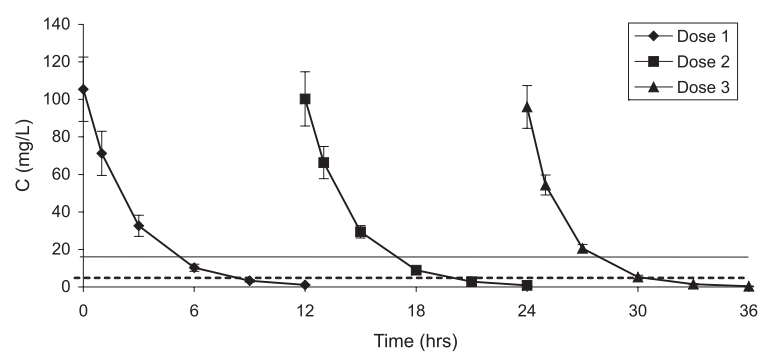

Figure 1 - Plasma drug decay for cefuroxime (1.5 g, IV) given to surgical patients undergoing coronary artery bypass grafting; $\mathrm{C}(\mathrm{mg} / \mathrm{L}$, mean/SEM vs T (hrs). ---- Equivalent to $4 \mathrm{mg} / \mathrm{L}$ (minimal inhibitory concentration: MIC). - Equivalent to $16 \mathrm{mg} / \mathrm{L}$ (4 x MIC) 
Table 1 - Kinetics of cefuroxime in patients submitted to coronary artery bypass grafting, n=17

\begin{tabular}{lllll}
\hline Cefuroxime & $\begin{array}{l}\text { Median } \\
(95 \% \mathrm{CI})\end{array}$ & & \\
& & & \\
\hline Dose $1.5 \mathrm{~g}$ IV, bolus & Kel( $\left.\mathrm{h}^{-1}\right)$ & Half-life(hour) & $\mathrm{CL}_{\mathrm{T}} \mathrm{mL} / \mathrm{min} / \mathrm{kg}$ & $\mathrm{VdL} / \mathrm{kg}$ \\
Reference $^{3}$ & 0.40 & 1.7 & 1.4 & 0.20 \\
$1^{\text {st }}$ dose & $0.38(0.36-0.42)$ & $1.8(1.7-2.0)$ & $1.4(1.1-1.6)$ & $0.19(0.15-0.26)$ \\
$2^{\text {nd }}$ dose & $0.36(0.34-0.46)$ & $1.9(1.5-2.0)$ & $1.5(1.0-1.9)$ & $0.25(0.16-0.30)$ \\
$P$ & .8125 & .8125 & .6875 & .1094 \\
$3^{\text {rd }}$ dose & $0.39(0.32-0.55)$ & $1.8(1.3-2.1)$ & $1.5(1.2-2.4)$ & $0.22(0.19-0.37)$ \\
$P$ & .8125 & .8125 & .1190 & .2188 \\
\hline$P:{ }^{2}$ & & & .190 \\
\hline
\end{tabular}

$P: 2^{\text {nd }}$ dose or $3^{\text {rd }}$ dose vs the $1^{\text {st }}$ dose; Statistically significant when $P<0.05$. Mann Whitney test; $\mathrm{CI}=$ confidence interval; Kel $=$ elimination rate constant, $\mathrm{CL}_{\mathrm{T}}=$ plasma clearance rate; $\mathrm{Vd}=$ apparent volume distribution

\section{DISCUSSION}

Several invasive procedures are performed during cardiac surgery that expose patients to opportunistic bacteria. Aseptic procedures, the training of the surgical team, and the correct antibiotic prophylaxis are important factors that contribute to the reduction of the incidence of postsurgical infections. Despite the efforts of infection control committees, these complications involving nosocomial infections have been reported in the hospitals in this country and worldwide. Data reported previously show an incidence of $5 \%$ to $10 \%$ of postsurgical infections in patients undergoing to cardiac surgery. ${ }^{6-8}$

As reported by the Infection Control Committee of Instituto do Coração (University of Medical School) the rates of postsurgical infections including superficial or deep infections, mediastinitis, thoracic osteomyelitis, and limb wound infections were lower than $10 \%$ over the past 5 years. However, none of the patients evaluated in this study protocol presented any postsurgical infection.

Since the 1960s, the prophylactic administration of antimicrobial agents has been proposed to reduce the incidence of these infections, and today it is an important routine procedure for patients undergoing surgeries such as cardiovascular interventions. Antibiotic prophylaxis substantially reduces the incidence of infections, the time of hospitalization, and consequently the costs of treatment, as reported previously.,10

A large number of different dose regimens with cefuroxime have been described for surgical prophylaxis, including a single 3 -g bolus IV dose before surgery, or the administration of several doses ( 3 to $4.5 \mathrm{~g}$ ), with regimens of, for instance, 1.5 -g IV bolus every 8 or every 12 hours, or a continuous infusion of $125 \mathrm{mg} / \mathrm{hr}$ for 24 hours. ${ }^{4,6-10}$

In this study, the antimicrobial agent was given as follows: $1.5 \mathrm{~g}$ starting preoperatively (first dose, given immediately before the beginning of surgery), and $1.5 \mathrm{~g}$ in the immediate and late postoperative period. In general, a minimal inhibitory concentration (MIC) for cefuroxime is equivalent to $4 \mathrm{mg} / \mathrm{L}$. However, a trough level of 4 -fold the minimal inhibitory concentration $(4 \times 4 \mathrm{mg} / \mathrm{L}=16 \mathrm{mg} / \mathrm{L})$ is recommended to improve prophylaxis, since the drug has a large therapeutic index, and adverse effects have not been reported as a consequence of high plasma concentrations. ${ }^{8,9,11,12}$

In the present study, plasma concentrations of cefuroxime were shown to reduce rapidly as a consequence of its short half-life, Figure 1. Data obtained after drug administration showed cefuroxime plasma concentrations below $16 \mathrm{mg} / \mathrm{L}$ after the sixth hour (4 times the minimum inhibiting concentration (MIC) of $4 \mathrm{mg} / \mathrm{L}$ ), and below the MIC after the $9^{\text {th }}$ hour, at all dosing times, both pre- and postsurgical.

No accumulation was registered at the $12^{\text {th }}$ hour (time dose interval), and consequently a single dose administration must be considered, since no residue was found after several doses of $1.5 \mathrm{~g}$, IV. Based on these considerations, the washout of cefuroxime was completed every 12 hours, as illustrated in Figure 1.

The kinetic disposition of cefuroxime was investigated based on plasma curve decay applying a 1-compartment open model using a quite simple, sensitive, selective, and low-cost micromethod, requiring only $200 \mu \mathrm{L}$ of plasma per sample. ${ }^{5}$

No significant difference in comparisons between the first, second, and third doses were observed in the kinetic parameters, elimination rate constant, biological half-life, plasma clearance, and apparent volume of distribution, as shown on Table 1. These findings were very close to those reported for healthy volunteers, ${ }^{3}$ and they suggest that the kinetic disposition of cefuroxime is unaltered by surgery in patients with preserved renal function.

Additionally, cefuroxime plasma concentrations reduced rapidly after the IV bolus for the surgical patients investigated (Figure 1); data obtained were close to the results reported previously in healthy volunteers. ${ }^{3}$

It is also known that the bactericidal action of the antimicrobial agent is not directly related to maximum plasma concentration reached, but to the period of time during which plasma levels are maintained at levels above 4 to 8 times the MIC. ${ }^{8-11}$

According to the exponential curve decay, shown in Figure 1 , the maximum plasma concentration reached was approximately $100 \mathrm{mg} / \mathrm{L}$ and fell rapidly to below $16 \mathrm{mg} / \mathrm{L}$ at the $6^{\text {th }}$ hour and below $4 \mathrm{mg} / \mathrm{L}$ at the $9^{\text {th }}$ hour after drug administra- 
tion. Considering the postoperative period ( $1^{\text {st }}$ and $2^{\text {nd }}$ day), data obtained suggest that the washout of cefuroxime was completed 12 hours after each of the second and the third doses.

A linear pharmacokinetics for cefuroxime was found at the dose regimen applied, since kinetic parameters for distribution and elimination of drug remained unchanged during and after surgery. The kinetic disposition of cefuroxime remained unaltered in patients undergoing coronary artery bypass grafting. To reduce the fluctuation in plasma lev- els, guaranteeing antibiotic prophylaxis in the peri-operative period, the dose regimen should be reviewed.

\section{CONCLUSION}

The results obtained allow us to suggest that the kinetic disposition of cefuroxime is unaltered by the surgery in patients undergoing $\mathrm{CABG}$ at the dose regimen of $1.5 \mathrm{~g}$ every 12 hours

\section{RESUMO}

Nascimento JWL, Carmona MJC, Strabelli TMV, Auler Jr JOC, Santos SRCJ. Farmacocinética da Cefuroxima na antibioticoprofilaxia de cirurgia cardíaca. Clinics. 2007;62(3):257-60.

OBJETIVO: Investigar os níveis plasmáticos e comparar a farmacocinética da cefuroxima durante e após cirurgia de revascularização do miocárdio.

MÉTODOS: Dezessete pacientes receberam três doses intravenosas de $1,5 \mathrm{~g}$ de cefuroxima, a cada 12 horas. Foram coletadas amostras de sangue nos tempos de 1, 3, 6, 9 e 12 horas após a primeira dose (durante a cirurgia) e após a segunda e terceira dose (administradas após a cirurgia). As amostras de sangue foram centrifugadas e armazenadas congeladas até o momento da análise. Os níveis plasmáticos da cefuroxima foram determinados através de cromatografia líquida, utilizando-se apenas $200 \mathrm{~mL}$ de plasma. A determinação da farmacocinética da cefuroxima foi realizada utilizando o software PK-solutions 2.0.

RESULTADOS: Todos os parâmetros cinéticos obtidos permaneceram inalterados após a adminstração da $1^{\text {a }}, 2^{\text {a }} \mathrm{e}$ $3^{\mathrm{a}}$ doses: meia vida de eliminação $1,8 \mathrm{~h}, 1,9 \mathrm{~h}$ and $1,8 \mathrm{~h}$, depuração 1,4, 1,5 and 1,5 mL/min/kg respectivamente. Adicionalmente, o volume aparente de distribuição, não se alterou durante ou após a intervenção: 0,19, 0,25 and 0,22 $\mathrm{L} / \mathrm{kg}$, após $1^{\mathrm{a}}, 2^{\mathrm{a}}$ e $3^{\mathrm{a}}$ dose, respectivamente. Os níveis plasmáticos obtidos após administração da cefuroxima reduziram rapidamente devido à alta depuração plasmática com conseqüente curta meia-vida plasmática, atingindo valores abaixo da concentração inibitória mínima a partir da $9^{\text {a }}$ hora da administração.

CONCLUSÕES: A disposição cinética da cefuroxima permanece inalterada em pacientes submetidos à cirurgia de revascularização do miocárdio, e com vistas à redução da flutuação no período perioperatório, o regime de dose para a antibioticoprofilaxia poderia ser revisto.

UNITERMOS: Cefuroxima, Farmacocinética, Antibiótico, Cromatografia, Cirurgia cardíaca

\section{REFERENCES}

1. Turna A, Kutlu CA, Ozalp T, Karamustafaoglu A, Mulazimoglu L, Bedirhan MA. Antibiotic prophylaxis in elective thoracic surgery: cefuroxime versus cefepime. Thorac Cardiovasc Surg. 2003;51:84-8.

2. (no authors listed) Current trends in antibiotic prophylaxis in surgery. Surgery. 2000;128:S14-8.

3. Emmerson AM. Cefuroxime axetil. J Antimicrob Chemother. 1988;22:101-4.

4. Harbi M. Antimicrobial prophylactic practice in surgical patients. East Afr Med J. 1998;75:703-07.

5. Nascimento JWL, Omosako CE, Carmona MJ, Auler Junior JOC, Santos SRCJ. Micromethod for plasma cefuroxime quantification through high performace liquid chromatography. Application to the prophylaxis of patients submitted to cardiac surgery. Braz J Pharmac Sci. 2003;39:265-72.

6. Jakob HG, Borneff-Lipp M, Bach A, von Puckler S, Windeler J, Sonntag $\mathrm{H}$, et al. The endogenous pathway is a major route for deep sternal wound infection. Eur J Cardiothorac Surg. 2000;17:154-60.
7. Kriaras I, Michalopoulos A, Michalis A, Palatianos G, Economopoulos $\mathrm{G}$, Anagnostopoulos C, et al. Antibiotic prophylaxis in cardiac surgery. J Cardiovasc Surg. 1997;38:605-10.

8. Pass SE, Miyagawa CI, Healy DP, Ivey TD. Serum concentrations of cefuroxime after continuous infusion in coronary bypass graft patients. Ann Pharmacother. 2001;35:409-13.

9. Jacobs MR. Optimisation of antimicrobial therapy using pharmacokinetic and pharmacodynamic parameters. Clin Microbiol Infect. 2001;7:589-96.

10. Trick WE, Scheckler WE, Tokars JI, Jones KC, Reppen ML, Smith EM, et al. Modifiable risk factors associated with deep sternal site infection after coronary artery bypass grafting. J Thorac Cardiovasc Surg. 2000;119:108-14.

11. Wenisch C, Bartunek A, Zedtwitz-Liebenstein K, Hiesmayr M, Parschalk B, Pernerstorfer T, et al. Prospective randomized comparison of cefodizime versus cefuroxime for perioperative prophylaxis in patients undergoing coronary artery bypass grafting. Antimicrob Agents. 1997;41:1584-8.

12. Craig WA, Ebert SC. Continuous infusion of beta-lactam antibiotics. Antimicrob Agents Chemother. 1992;36:2577-83. 